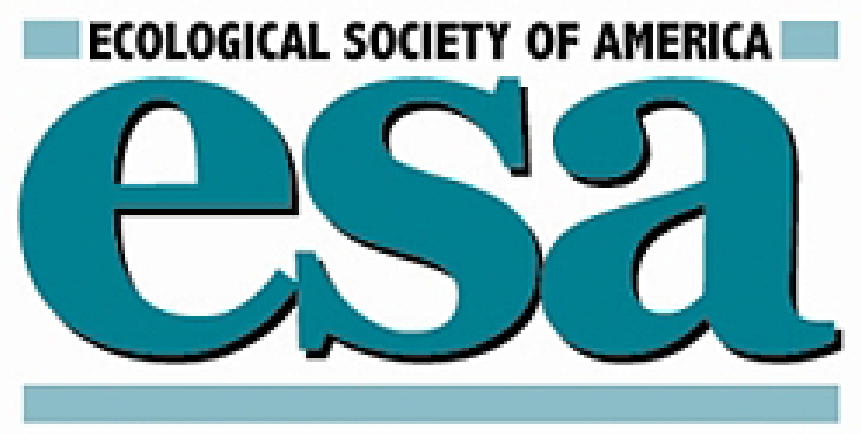

Comparative Water Relations of Phreatophytes in the Sonoran Desert of California Author(s): Erik Tallak Nilsen, M. Rasoul Sharifi and Philip W. Rundel

Source: Ecology, Vol. 65, No. 3 (Jun., 1984), pp. 767-778

Published by: Ecological Society of America

Stable URL: http://www.jstor.org/stable/1938049

Accessed: 13/03/2014 09:49

Your use of the JSTOR archive indicates your acceptance of the Terms \& Conditions of Use, available at http://www.jstor.org/page/info/about/policies/terms.jsp

JSTOR is a not-for-profit service that helps scholars, researchers, and students discover, use, and build upon a wide range of content in a trusted digital archive. We use information technology and tools to increase productivity and facilitate new forms of scholarship. For more information about JSTOR, please contact support@jstor.org. 


\title{
COMPARATIVE WATER RELATIONS OF PHREATOPHYTES IN THE SONORAN DESERT OF CALIFORNIA ${ }^{1}$
}

\author{
ERIK TAllak NiLSEN \\ Department of Biology, Virginia Polytechnic Institute and State University, \\ Blacksburg, Virginia 24061 USA \\ AND \\ M. Rasoul Sharifi ${ }^{2}$ And Philip W. Rundel ${ }^{2}$ \\ Department of Ecology and Evolutionary Biology, University of California, \\ Irvine, California 92717 USA
}

\begin{abstract}
The seasonal and diurnal water relations were compared among six desert phreatophytes, two evergreen shrubs, and one deciduous shrub. All species were located in one wash woodland in the Sonoran Desert of southern California. There are several mechanisms by which these phreatophytes have adapted to the desert environment. One group of winter-deciduous phreatophytes (Olneya tesota, Prosopis glandulosa, and Acacia greggii) experienced summer midday leaf water potentials below -4.0 $\mathrm{MPa}$. These phreatophytes had a series of physiological mechanisms for tolerating summer water stress, including seasonal and diurnal osmotic adjustment and the maintenance of high leaf conductance at low leaf water potential. Osmotic adjustment of these three phreatophytes was similar to or greater than that of two evergreen species (Larrea tridentata and Simmondsia chinensis). Dalea spinosa, a stem-photosynthetic phreatophyte, avoided water stress by maintaining a very small leaf area. The summer-deciduous phreatophytes (Hyptis emoryi, and Chilopsis linearis) demonstrated mechanisms of drought avoidance such as change in leaf biomass and low summer leaf conductance. Little osmotic adjustment occurred in the summer-deciduous phreatophytes.

The phreatophytic species studied in this investigation have evolved adaptations to water stress that are similar to those of deciduous and evergreen shrubs of the Sonoran Desert. Desert phreatophytes are a complex group of species with varied adaptive mechanisms to tolerate or avoid drought and should not be considered simply as a group of species that avoid desert water stress by utilizing deep ground water unavailable to other desert species of drought tolerance and avoidance.
\end{abstract}

Key words: Acacia greggii; Chilopsis linearis; Dalea spinosa; Hyptis emoryi; leaf conductance; Olneya tesota; osmotic adjustment; phreatophytes; Prosopis glandulosa; Sonoran Desert; water relations.

\section{INTRODUCTION}

Comparative investigations of the water relations characteristics of various growth-forms within communities are available for many ecosystems. In mediterranean ecosystems many comparisons of water relations in evergreen and drought deciduous species have been conducted (Mooney and Kummerow 1979, Poole and Miller 1981). Similar comparisons have been made in eastern deciduous forests between broadleaf evergreen and broadleaf deciduous taxa (Cline and Campbell 1976, Roberts et al. 1979). Some comparisons in desert ecosystems have been made between deciduous and evergreen shrubs (Bennert and Mooney 1979) and between a phreatophyte and an evergreen or deciduous shrub (Strain 1970, Szarek and Woodhouse 1977), but most detailed work has been limited to a few species.

While a large volume of literature is available on the water relations of desert shrubs (e.g., Walter and Sta-

\footnotetext{
${ }^{1}$ Manuscript received 20 December 1982; revised 1 June 1983; accepted 3 June 1983.

${ }^{2}$ Present address: Laboratory of Biomedical and Environmental Sciences, University of California, Los Angeles, California USA.
}

delman 1974) and general studies of phreatophyte ecology (see Felker 1979), comparative studies of the water relations of desert phreatophytes and associated species have been limited (see Strain 1970, Szarek and Woodhouse 1976, Mooney et al. 1980, Nilsen et al. 1981, 1983). Generalizations have been commonly made that desert phreatophytes as a group have low water stress tolerance and high water stress avoidance as a result of their deep rooting system (Levitt 1980).

Observations of several phreatophytic trees in the Sonoran Desert made by our research group clearly indicated that there was great variability in adaptive strategies among species, particularly in relation to their phenology (E. T. Nilsen, personal observation). In this paper we compare the seasonal and diurnal water relations characteristics of a series of important desert phreatophytes and other perennial growth forms in the same habitat in the Sonoran Desert of southern California.

\section{Site AND Species Description}

Our field measurements were carried out at Nude Wash in Anza Borrego State Park (San Diego County, California), a woodland community which is located 


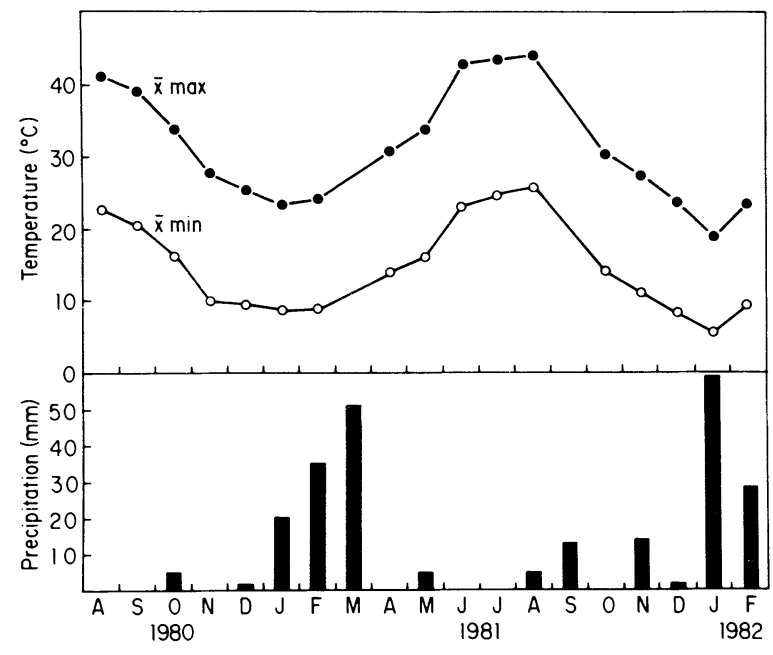

FIG. 1. Climatic conditions in Anza Borrego State Park headquarters ( $250 \mathrm{~m}$ elevation) near Nude Wash.

in an outwash canyon at $300 \mathrm{~m}$ elevation in the Vallecito Mountains. The wash vegetation is dominated by woody, phreatophytic, large shrubs and trees as well as scattered evergreen and drought deciduous shrubs. Most important upper Sonoran Desert wash woodland genera are represented in the flora of Nude Wash, with the exception of Cercidium microphyllum.

The climatic conditions of the region, as recorded at Anza Borrego State Park headquarters (elevation 250 m), from August 1980 to February 1982 are shown in Fig. 1. The highest mean-maximum temperatures are reached between July and September, when values are often $>40^{\circ} \mathrm{C}$. At this time daily maximum values may reach $48^{\circ}-50^{\circ}$. Lowest mean-minimum temperatures are reached between November and March with values as low as $5^{\circ}-7^{\circ}$. Daily minimum temperatures may rarely reach $0^{\circ}$ in January and February. Most precipitation occurs during the winter and early spring (December-March). Summers are dry with occasional fall thunderstorms. The mean annual precipitation at the Park Headquarters is $75 \mathrm{~mm}$ (20-yr record), less than the precipitation during $1980(163 \mathrm{~mm})$ and $1981(147$ $\mathrm{mm}$ ).

Even though several species had individuals located on the walls of the wash canyon, only individuals on the floor of Nude Wash were used in this study so that all species would be in as uniform a habitat as possible.

The term phreatophyte is used in this article for those species capable of utilizing ground water outside the period of maximum rainfall. In this case water is accumulated from deep ground water resources. In this study Hyptis emoryi is an exception to the above definition, yet the water relations characteristics presented in this article indicated that Hyptis emoryi does have access to ground water unavailable to other nonphreatophytic shrubs in this wash. Six of the species chosen were woody phreatophytes almost exclusively located in wash woodlands of the upper Sonoran Desert (Hastings et al. 1972). Three of these phreatophytes are winter-spring deciduous (Prosopis glandulosa var. torreyana, Olneya tesota, Acacia greggii). Two phreatophytes, Chilopsis linearis and Hyptis emoryi, are summer deciduous. One of the phreatophytes has very short-lived ephemeral leaves (Dalea spinosa) and is best classified as stem-photosynthetic. All are shrubs to small trees.

Several of these phreatophytic trees/shrubs are exclusively restricted to areas of ground water in the upper Sonoran Desert ( $P$. glandulosa, H. emoryi, C. linearis, and D. spinosa). Olneya tesota and A. greggii are occasionally found on canyon walls and outwash bajades, but their maximum distribution occurs in wash areas of the California Sonoran Desert (Hastings et al. 1972, Munz 1974). Deep rooting has been measured only with $P$. glandulosa (Phillips 1963, Sharifi et al. 1982), although personal observation of the roots in all phreatophytic species in this study indicate deep rooting $(>1 \mathrm{~m})$.

Two evergreen shrubs were studied, Larrea tridentata and Simmondsia chinensis. Although these species are found in the wash, they are both more commonly found in rockier and higher areas of the Sonoran Desert (Munz 1974). Measurements were also taken on one drought-deciduous shrub, Encelia farinosa, which has been shown to lack access to deep ground water resources (Smith and Nobel 1977). Measurements were also made on the desert ephemeral vine Cucurbita digitata. Taxonomy used here follows that of Munz (1974).

\section{Methods And Materials}

Seasonal and diurnal measurements of predawn and midday water potentials were collected with a pressure chamber (PMS Incorporated, Corvalis, Oregon; Model 1000) apparatus (Scholander et al. 1965, Ritchie and Hinckley 1975). Water potential measurements here refer to xylem-pressure-potential measurements of shoots in all cases except $P$. glandulosa, where leaves were used. Three individuals of each species were chosen and 2-3 measurements were taken per individual at predawn and midday. Values presented are means for each species. Diurnal cycles of leaf conductance were measured with a steady state porometer (LI-COR Incorporated, Lincoln, Nebraska; Model 1600). Five leaves were chosen on two plants of each species for the leaf conductance measurements.

Measurements of other water relations components (turgor, osmotic, and matric potential; water deficit at the turgor loss point) were determined by the pressurevolume (PV) technique (Scholander et al. 1965, Tyree and Hammel 1972). The particular method used for all species closely followed the "Hammel" method (Tyree et al. 1978) and has been explained in detail elsewhere (Tyree and Hammel 1972). Shoots were collected at dawn (except for the evaluation of diurnal 
osmotic adjustment), recut under water and brought to full saturation $(24 \mathrm{~h})$ before the PV curve was determined. On each collection date 5-10 PV curves were determined for each species. For calculations and specifics about the PV technique see Tyree and Hammel 1972. Critical characteristics of PV curves, such as excess (noncollected) water loss, rate of pressure adjustment, length of resaturation period, attainment of the equilibrium pressure, etc., follow guidelines of Tyree and Hammel (1972).

Seasonal phenological patterns were determined by labeling branches ( $n=10$ per species) and determining the number of leaves per branch. The percentage of the maximum number of mature leaves was calculated to indicate seasonal trends in leaf biomass. These values are presented as qualitative seasonal trends. Small changes in specific leaf mass occurred (data not reported) which did not influence the relationship of the number of leaves to the leaf biomass in shoots.

Diurnal cycles of microclimate were determined on 7 January, 22 May, and 4 August 1982. Photosynthetically active radiation (PAR) was measured at the leaf angle with a LI-COR quantum sensor. Temperature was recorded at $1 \mathrm{~m}$ elevation by a shaded copperconstantan thermocouple. Measurements of leaf temperature were determined by implanting 36-gauge copper-constantan thermocouples $(0.13-\mathrm{mm}$ diameter) into several leaves (abaxial surface) of each species. Wind velocity was measured at $1 \mathrm{~m}$ in the canopy every $15 \mathrm{~s}$ with a hot-wire anemometer (Weather Measure $\mathrm{W} 241 \mathrm{M}$ ) and the average for a 2-min span was recorded each hour. The vapor pressure gradient was calculated as per Campbell (1977) from measurements of wet and dry bulb temperatures (recorded by a sling psychrometer) and leaf temperature. Micrometerological data were collected and stored with a Campbell Scientific Incorporated (Logan, Utah) data recording system; Model CR21 micrologger.

\section{RESULTS}

Each phreatophyte species investigated had a distinct seasonal progression of leaf production and loss (Fig. 2). Every phreatophyte studied was deciduous, but the length of the deciduous period and the season when abscission occurred varied among species. Three legumes, Prosopis glandulosa, Acacia greggii, and Olneya tesota, were leafless for $\approx 1$ mo during the late winter to spring, in February, March-April, and AprilMay, respectively. Although all the phreatophytes initiated productivity at the same time, $P$. glandulosa produced leaves before flowers, $A$. greggii produced flowers and leaves simultaneously, while $O$. tesota produced flowers before leaves.

Chilopsis linearis and $H$. emoryi were deciduous in the summer, losing most leaves during June and AprilMay, respectively. Hyptis emoryi, however, maintained a small population of small xeromorphic leaves throughout the summer, as described by Smith and Nobel (1978). Encelia farinosa and $H$. emoryi, the drought-deciduous shrubs, had similar phenological patterns. Leaf production by $C$. linearis occurred later than that of $H$. emoryi but at a similar time to the winter-deciduous phreatophytes. Chilopsis linearis also had a small, second growth period following the main flowering period in August.

The two evergreen species (L. tridentata and S. chinensis) had phenological patterns distinctly different from each other. Simmondsia chinensis did not lose any leaves over the 18-mo observation period. In contrast, $L$. tridentata demonstrated a high rate of leaf turnover. Approximately $70 \%$ of the current leaves and all of the remaining last year's leaves abscised between July and October.

Dalea spinosa is considered an ephemeral-leaf species similar to Cercidium microphyllum (Adams et al. 1967) and Fouquieria splendens. The data presented here indicate that $D$. spinosa is winter deciduous (Fig. 2). However, the $D$. spinosa leaves are so small that they represent an insignificant portion of the total transpirational surface $(>0.1 \%$; E. T. Nilsen et al., personal observation), making $D$. spinosa virtually leafless during the summer as well. Cucurbita digitata was the most ephemeral species studied, with two equivalent periods of leaf development during January-March and August-September. These two growth periods corresponded to the periods of greatest rainfall (Fig. 1).

The species studied can be grouped on the basis of their phenology and their relative leaf water potentials $(\psi)$. The evergreen shrubs (L. tridentata, S. chinensis) had lower $\psi$ than the phreatophytes during August 1981, while the drought-deciduous species $E$. farinosa, and Beleporone californica (used here for comparison), had equal or lower $\psi$ than the phreatophytes (Fig. 3). Among the phreatophytes, the winter-deciduous species had considerably lower $\psi$ than the summer-deciduous and stem-photosynthetic phreatophytic species. The root succulent (Hendrix 1982) Cucurbita digitata had the highest $\psi$ values.

Drought-deciduous phreatophytes (Chilopsis linearis, Hyptis emoryi) experienced the highest seasonal $\psi$, while the winter-deciduous phreatophytes (O. tesota, $P$. glandulosa, A. greggii) experienced considerably lower $\psi$ (differences significant at $P<.01 ; F$ test), particularly during the summer months (Fig. 4B). Although $O$. tesota is grouped with the winter-deciduous phreatophytes, its leaf phenology is intermediate, with the leafless period in late May-early June. This caused the summer decrease in midday $\psi$ to be out of phase with the other winter-deciduous phreatophytes (Fig. 4A). As a result, the inclusion of $O$. tesota with the winter-deciduous phreatophytes decreased the difference between the water potentials of the summer- and winter-deciduous phreatophytes (Fig. 4B). The decrease in midday $\psi$ during the summer is associated with increasing leaf biomass of the winter-deciduous 


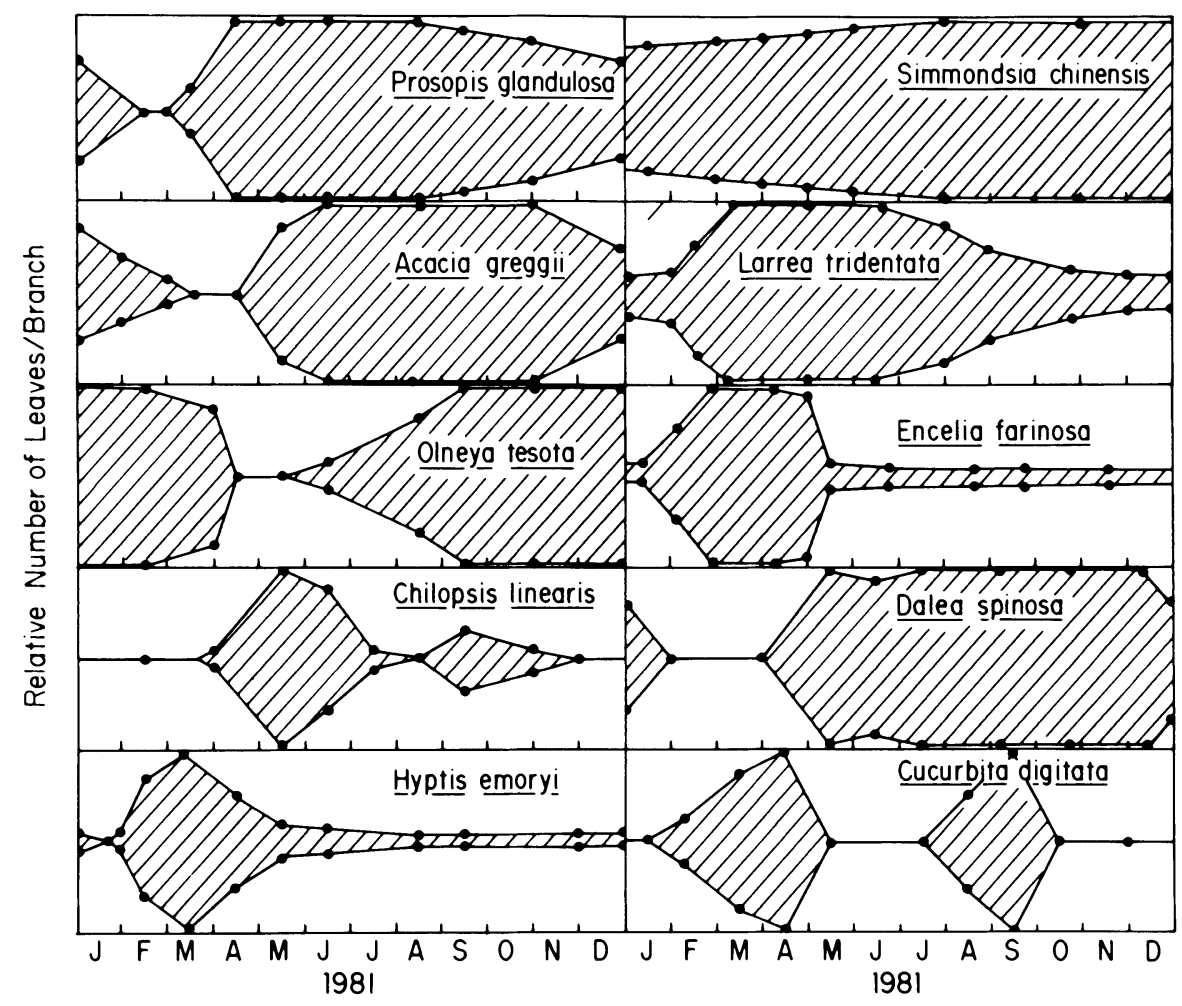

FIG. 2. Phenogram of relative number of leaves for 10 wash-woodland species in Nude Wash. Shaded area designates the number of leaves relative to the yearly maximum number of leaves for each species.

phreatophytes plus the increasing environmental water stress during this season.

The evergreen species in the wash $(S$. chinensis and L. tridentata) had the lowest midday $\psi$ throughout the year (Fig. 4B). The summer decrease in $\psi$ did not correspond to increasing leaf biomass in these species. The midday and predawn $\psi$ values for the drought-decid-

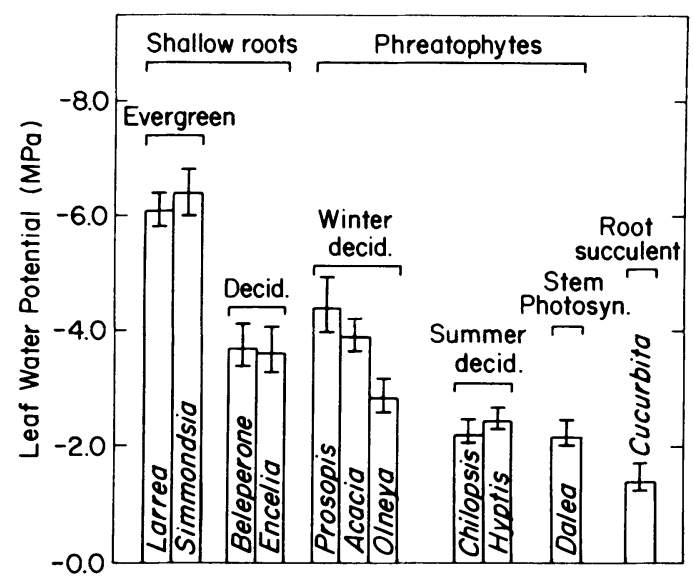

Fig. 3. Midday water potentials for species found in Nude Wash during August 1981. Error bars equal \pm 2 standard errors of the means ( $n=6$ measurements/species). uous shrub (Encelia farinosa) were intermediate between the evergreen shrubs and the winter-deciduous phreatophytes. The Cucurbita digitata midday $\psi$ never decreased below $-2.0 \mathrm{MPa}$ throughout the two growing seasons and was normally between -1.0 and -1.25 $\mathrm{MPa}$. (Data for $E$. farinosa and $C$. digitata are not presented in Fig. 4B.)

The trends in predawn $\psi$ (Fig. 5A), which indicate background water availability in the rooting zone (Slatyer 1967), were very similar to those of midday $\psi$ (Fig. 4A). Thus, the summer-deciduous phreatophytes have the best water availability year-round. The winter-deciduous phreatophytes have intermediate water availability during July through December, during which time the evergreen shrubs have the least water available. During February and March, the predawn $\psi$ indicates similar environmental water availability for all the species and growth forms (Fig. 5A, B). Decreases in predawn $\psi$ reflect only general decreases in environmental water availability, since predawn $\psi$ is also influenced by changes in the osmotic potential.

The microclimatic conditions for typical days during three seasons are shown in Fig. 6. PAR was similar on all three dates. The photoperiod increased from January to August as did the total daily photon flux. Temperature in January and May were similar, reaching a maximum of $26^{\circ} \mathrm{C}$ and $29^{\circ}$, respectively, and a mini- 


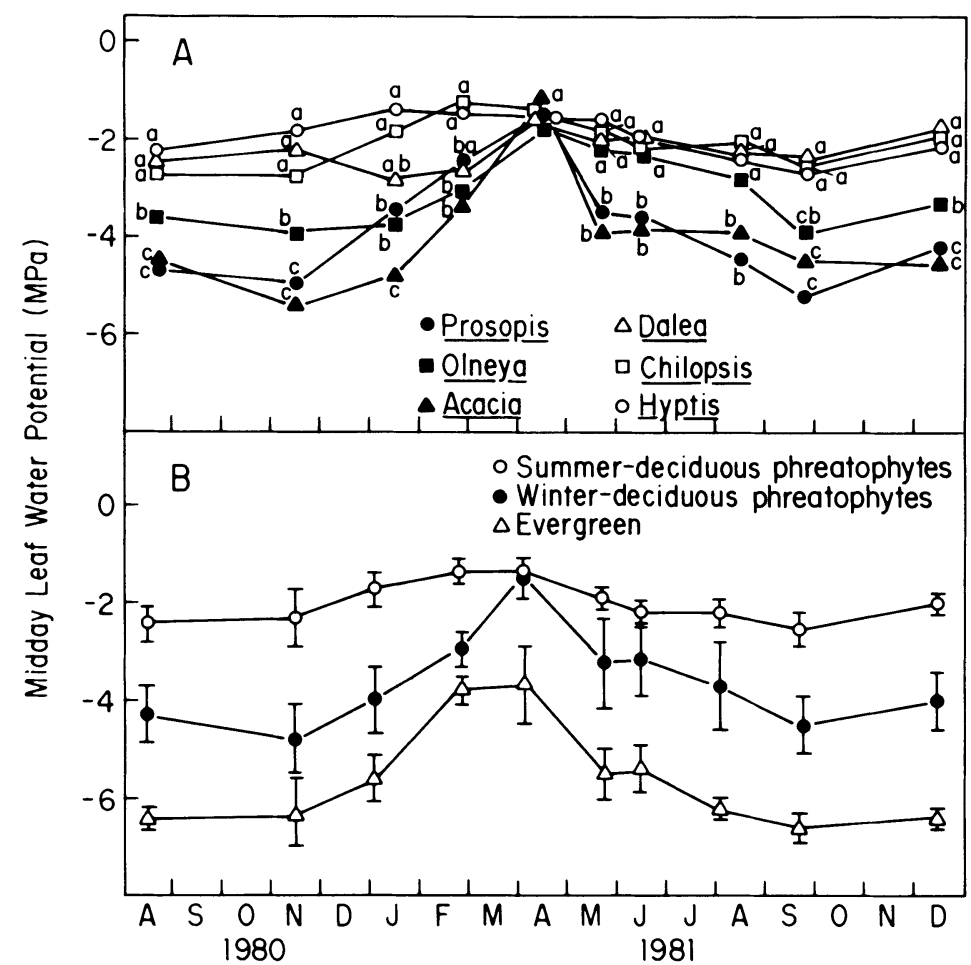

FIG. 4. A. Seasonal course of midday leaf water potential for six phreatophytic species in Nude Wash. Letters correspond to significant differences between species within a sampling date $P<.05$ ( $F$ test). B. Seasonal course of mean, midday, leaf water potential for groups of species based on growth phenology. Errors bars equal 2 standard errors on each side of the mean.

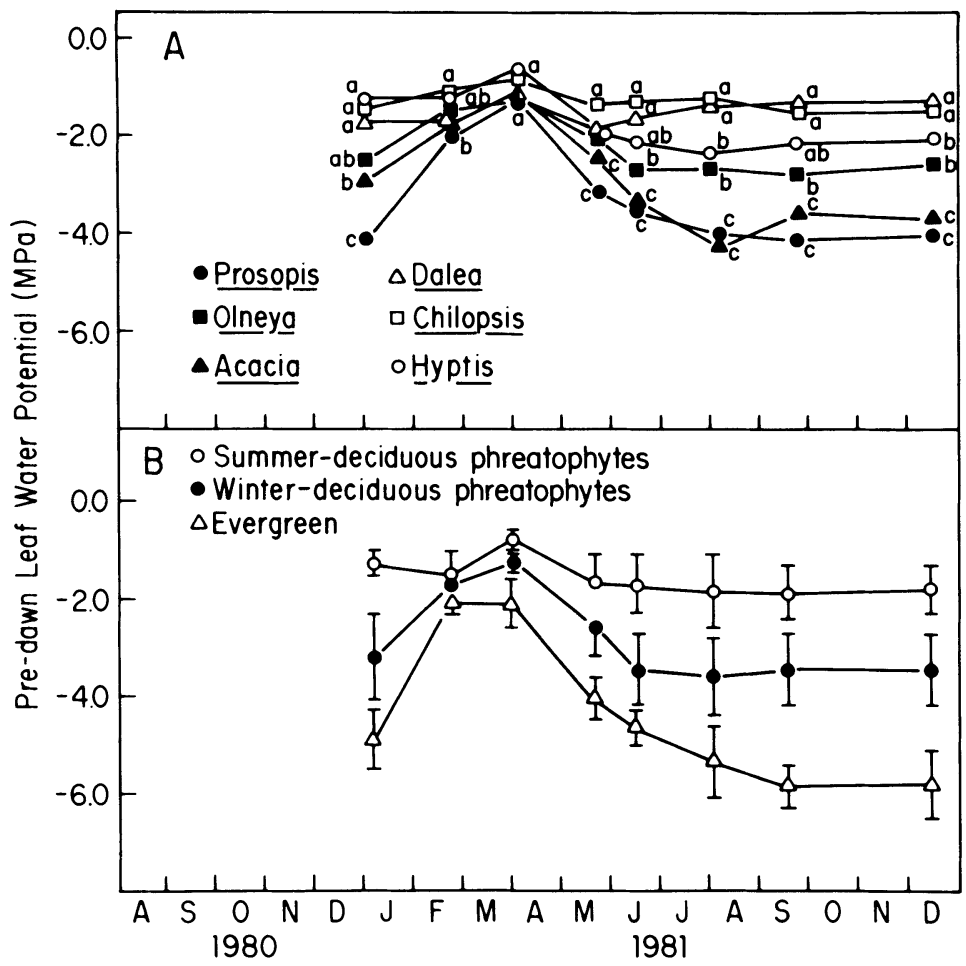

FIG. 5. A. Seasonal course of predawn leaf water potential for six phreatophytic species in Nude Wash. Letters correspond to significant differences between species within a sampling date at $P<.05$ ( $F$ test). B. Seasonal course of mean predawn leaf water potential for several groups of species based on growth phenology. Error bars equal 2 standard errors on each side of the mean. 


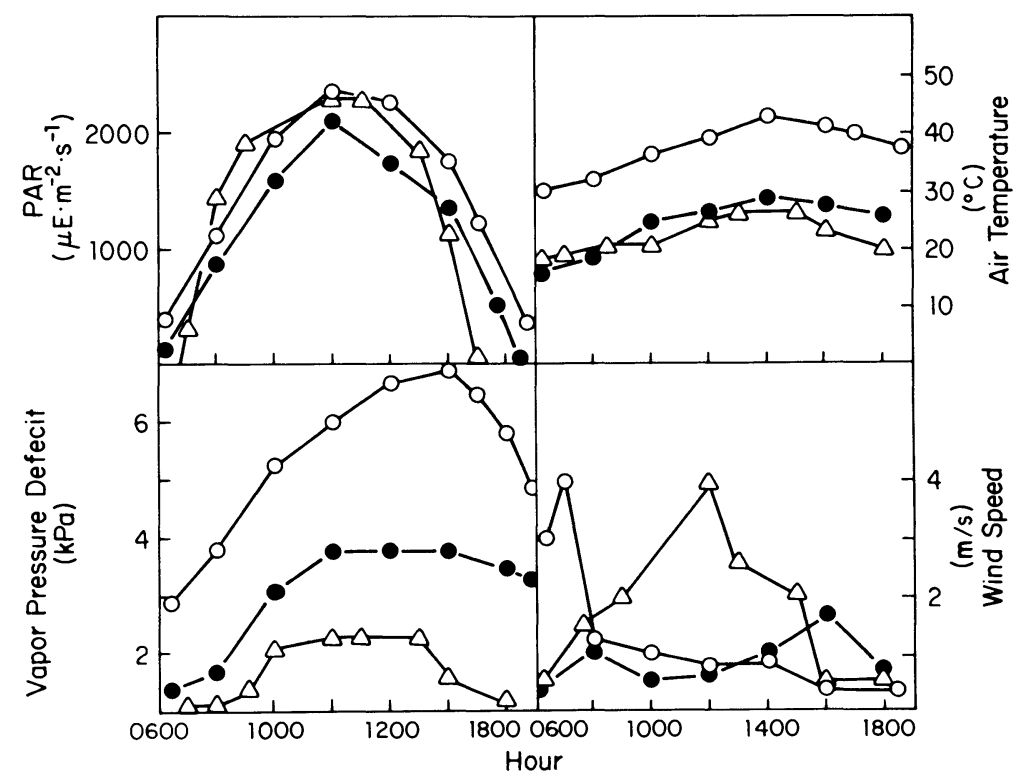

FIG. 6. Diurnal cycles (PST) of microclimatic conditions in Nude Wash on three dates; $\Delta=7$ January $1981, \bullet=22$ May $1981,0=4$ August 1981. PST $=$ Pacific Standard Time .

mum of $15.5^{\circ}$ and $17.5^{\circ}$, respectively. August temperatures were much higher than January or May, reaching a maximum of $45^{\circ}$, with $8 \mathrm{~h}>35^{\circ}$, and a minimum of $30^{\circ}$. January had the lowest vapor pressure deficit (VPD) values (maximum $=2.3 \mathrm{kPa}$ ), May was intermediate (maximum $=3.8 \mathrm{kPa}$ ) and August had the highest (maximum $=6.9 \mathrm{kPa})$. Wind characteristics were variable on the three chosen dates. In general, the microclimatic conditions of August were most desiccating because of the high temperatures, high VPD, and long photoperiod.

Diurnal cycles of leaf $\psi$ for six species (Fig. 7) are consistent with species differences described for predawn and midday $\psi$. The August $\psi$ cycles showed the least diurnal variation in comparison to other dates, while the January cycles showed the greatest diurnal variation except for $H$. emoryi and $E$. farinosa. Hyptis emoryi only had a small diurnal variation in $\psi$ in August and January because most leaves had abscised. There was an initial rapid drop in $\psi$ during August for $E$. farinosa followed by a gradual increase.

Leaf conductance values for $P$. glandulosa and $A$. greggii were significantly higher than for all other species $(P<.01 ; F$ test, Fig. 8$)$, and both had midday stomatal closure in May but not in August, as did E. farinosa and to some degree $O$. tesota. Similar results were found for P. glandulosa at another wash community (Nilsen et al. 1983). Even though $\psi$ values were considerably lower in August than in May for P. glandulosa, A. greggii, and $O$. tesota (Fig. 7), leaf conductance values were the same or higher in August than in May (Fig. $8)$. This indicates a change in the relationship between leaf conductance and water potential (Nilsen et al. 1981).

Pressure-volume (PV) relationships of leaf water po- tential $(\psi)$, osmotic potential $(\pi)$, and turgor potential $(\tau)$, and matric potential $(m)$ for eight species in September 1982 are shown in Fig. 9. Considerable vari-

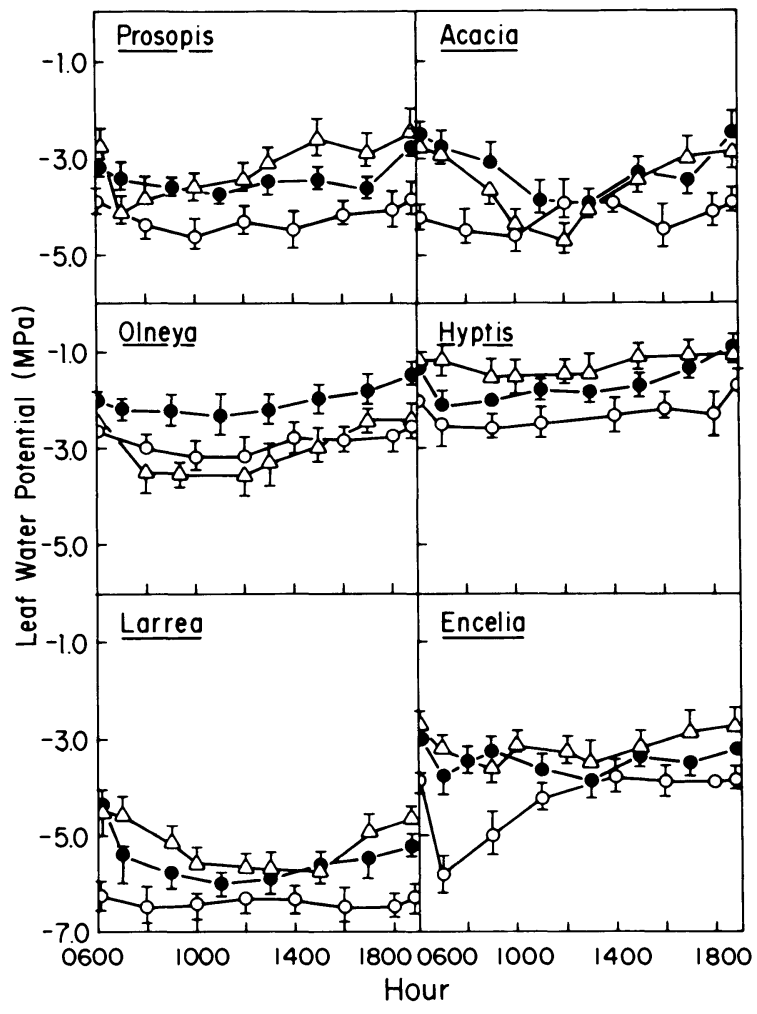

FIG. 7. Diurnal cycles (PST) of leaf water potential for six species in Nude Wash, on three dates; $\Delta=7$ January 1981, - $=22$ May $1981, \mathrm{O}=4$ August 1981. 


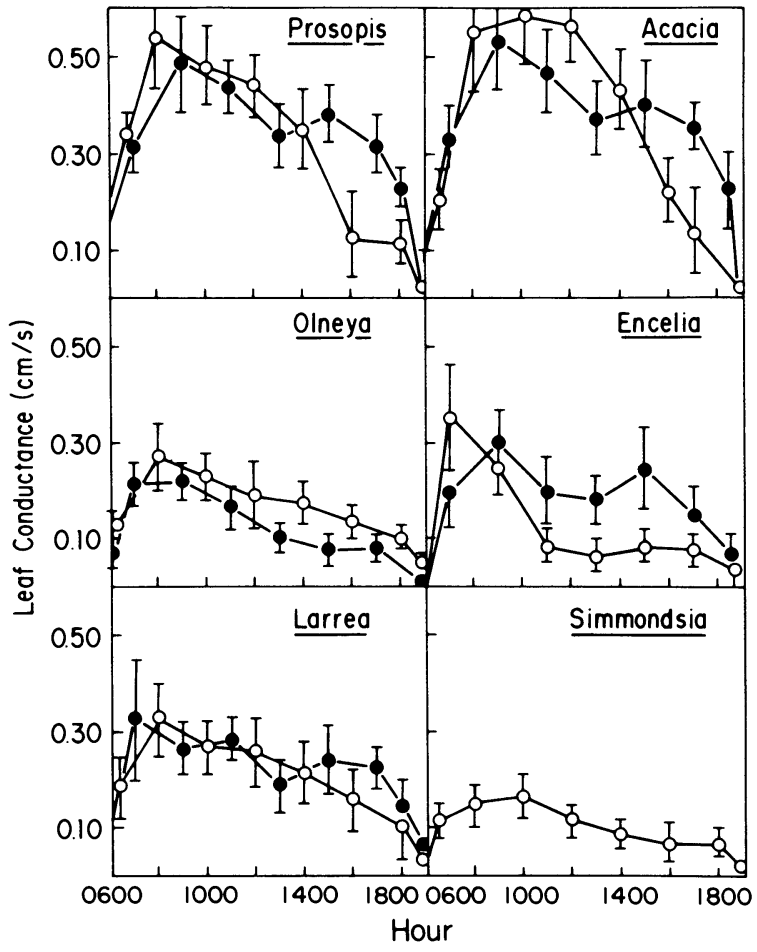

FIG. 8. Diurnal cycles (PST) of leaf conductance for six species in Nude Wash on two dates, $\bullet=22$ May 1981, $\mathrm{O}=$ 4 August 1981. ability in osmotic potential was found among the five phreatophytes represented. Prosopis glandulosa and $A$. greggii had the lowest osmotic potential at the turgor loss point $\left(\psi_{s}^{0}\right), O$. tesota and $C$. linearis were intermediate, and $H$. emoryi had the highest. There was a similar relationship for the osmotic potential at full turgor $\left(\psi_{s}^{100}\right)$. There were only small differences in the water deficit at the turgor loss point $\left(\mathrm{WD}^{\circ}\right)$ between the phreatophytes $(0.22-0.30)$. Prosopis glandulosa and O. tesota maintained turgor to the lowest water deficits. The osmotic potential characteristics of $L$. tridentata and $S$. chinensis were most similar to $A$. greggii and $P$. glandulosa values (Fig. 9).

These data indicate that $P$. glandulosa, A. greggii, $L$. tridentata, and $S$. chinensis are the most drought tolerant in September because of their ability to maintain turgor at lower leaf water potentials. Olneya tesota, $C$. linearis, and $E$. farinosa seem to be intermediate and $H$. emoryi is the least drought resistant because of the high water potential and low water deficit at the turgor loss point. The pressure-volume diagrams were from only one point in time and there is a diversity of phenologies among these species. Therefore, seasonal PV data will be a better representation of relative drought tolerance.

The annual minimum osmotic potential values were lowest in P. glandulosa, A. gregii, L. tridentata, and $S$. chinensis (Table 1). These low osmotic potentials oc-

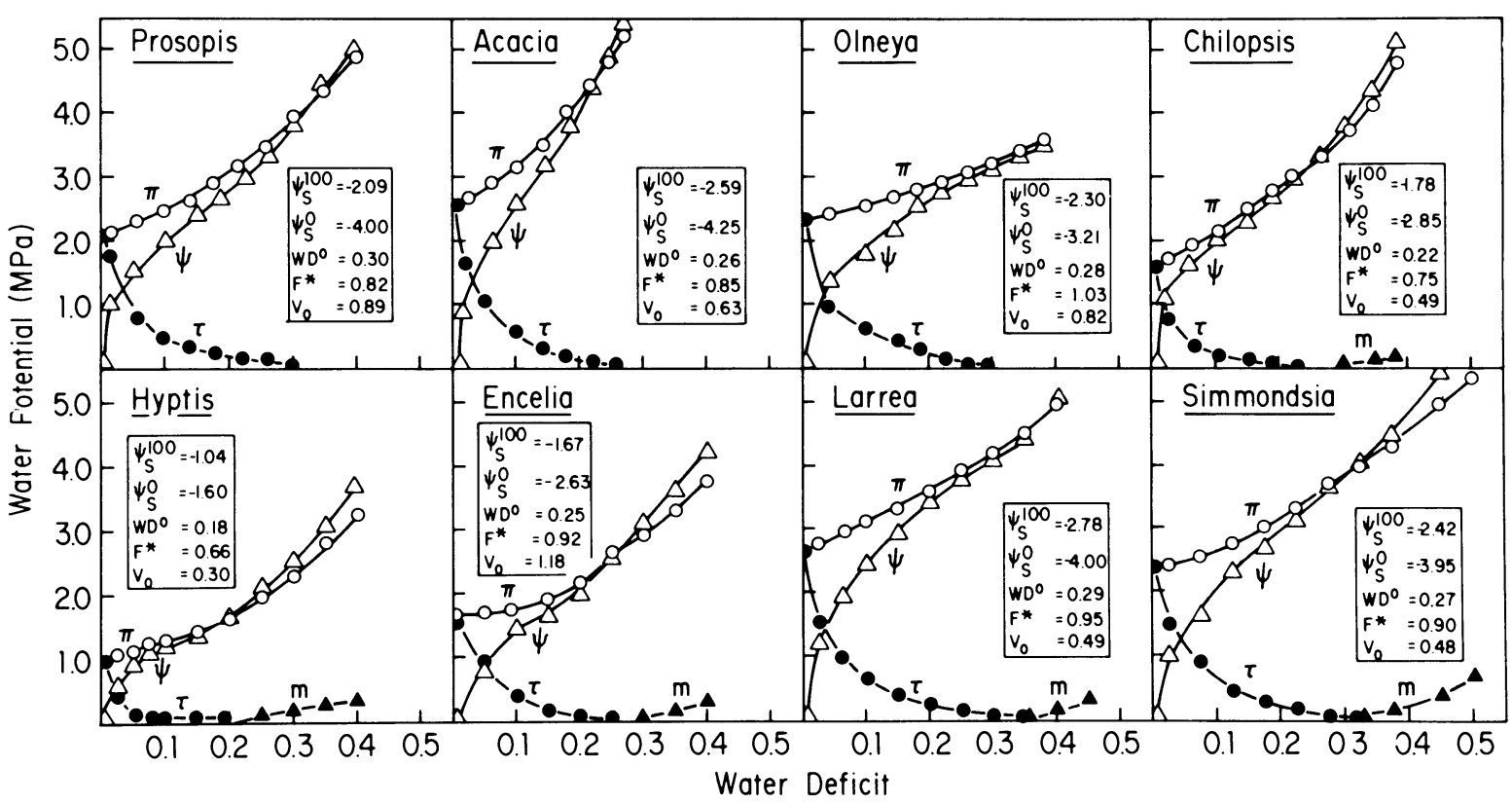

FIG. 9. Diagrams of water relations components against water deficit for eight species from Nude Wash, California. Symbols are: $\psi=$ leaf water potential, $\pi=$ osmotic potential, $\tau=$ turgor potential, $m=$ matric potential, $\psi_{s}^{100}=$ osmotic potential at full turgor, $\psi_{s}^{0}=$ osmotic potential at zero turgor, $\mathrm{WD}^{0}=$ water deficit at zero turgor, $\mathrm{F}^{*}=$ relative volume of nonbound symplastic water, $\mathrm{V}_{\mathrm{o}}=$ volume of osmotically active water. All water potentials are negative except turgor $(\tau)$, which is positive. 
TABLE 1. Mean values for osmotic potentials at full turgor $\left(\psi_{s}^{100}\right)$ and zero turgor $\left(\psi_{s}{ }^{0}\right)$, and water deficits at the turgor loss point $\left(\mathrm{WD}^{\circ}\right)$ derived from pressure-volume curves for several desert species. Values with the same letter superscripts are not significantly different $(n=5 ; P<.05, F$ test $)$.

\begin{tabular}{|c|c|c|c|c|c|c|}
\hline \multirow[b]{2}{*}{ Species } & \multicolumn{3}{|c|}{ Seasonal minimum } & \multicolumn{3}{|c|}{ Maximum } \\
\hline & $\begin{array}{c}\psi_{s}^{100} \\
(\mathrm{MPa})\end{array}$ & $\begin{array}{c}\psi_{s}^{0} \\
(\mathrm{MPa})\end{array}$ & Date & $\begin{array}{c}\Delta \psi_{s}^{0} \\
(\mathrm{MPa})\end{array}$ & $\mathrm{WD}^{0}$ & $\Delta \mathrm{WD}^{\circ}$ \\
\hline Prosopis glandulosa & $-2.98^{b}$ & $-4.00^{\mathrm{ab}}$ & Sep 81 & $1.56^{\mathrm{b}}$ & $0.34^{a}$ & $0.10^{\mathrm{ab}}$ \\
\hline Olneya tesota & $-2.98^{\mathrm{b}}$ & $-3.74^{b}$ & Jan 82 & $2.14^{\mathrm{a}}$ & $0.28^{\mathrm{ab}}$ & $0.04^{\mathrm{b}}$ \\
\hline Acacia greggii & $-2.20^{\mathrm{bc}}$ & $-4.25^{\mathrm{a}}$ & Sep 81 & $1.00^{c}$ & $0.30^{\mathrm{ab}}$ & $0.04^{\mathrm{b}}$ \\
\hline Chilopsis linearis & $-1.70^{\mathrm{c}}$ & $-2.51^{c}$ & Aug 81 & $1.50^{\mathrm{b}}$ & $0.24^{b}$ & $0.06^{\mathrm{ab}}$ \\
\hline Hyptis emoryi & $-1.18^{\mathrm{d}}$ & $-1.72^{\mathrm{d}}$ & May 81 & $0.52^{\mathrm{d}}$ & $0.20^{\mathrm{b}}$ & $0.15^{\mathrm{a}}$ \\
\hline Encelia farinosa & $-1.67^{c}$ & $-2.63^{c}$ & Aug 81 & $1.05^{c}$ & $0.25^{\mathrm{b}}$ & $0.15^{\mathrm{a}}$ \\
\hline Larrea tridentata & $-2.78^{b}$ & $-5.26^{\mathrm{a}}$ & Feb 82 & $1.65^{\mathrm{b}}$ & $0.39^{a}$ & $0.08^{\mathrm{ab}}$ \\
\hline Simmondsia chinensis & $-3.70^{\mathrm{a}}$ & $-5.00^{\mathrm{a}}$ & Sep 82 & $1.24^{\mathrm{bc}}$ & $0.32^{\mathrm{ab}}$ & $0.12^{\mathrm{ab}}$ \\
\hline
\end{tabular}

curred in September for S. chinensis, A. greggii, and $P$. glandulosa, but $L$. tridentata did not reach its lowest value until February 1982 (January for O. tesota). Chilopsis linearis and $E$. farinosa had intermediate minimum osmotic potentials, which occurred in August. The minimum osmotic potential of the season for $H$. emoryi, occurring in May, was significantly higher than for the other species.

The magnitude of seasonal osmotic adjustment is a good index of a species' ability to adapt to changing water stress (Walter and Stadelman 1974, Hellebust 1976). Although $O$. tesota did not have the lowest osmotic potential, this species had the largest seasonal osmotic adjustment (Table 1). Prosopis glandulosa, $C$. linearis, and $L$. tridentata had seasonal osmotic adjustments of $\geq 1.5 \mathrm{MPa}$. Simmondsia chinensis, $A$. greggii, and E. farinosa also had seasonal osmotic adjustments between 1.0 and $1.25 \mathrm{MPa}$, while $H$. emoryi had the lowest seasonal osmotic adjustment.

Maximum water deficits $\left(\mathrm{WD}^{\circ}\right)$ at the turgor loss point $\left(\psi_{s}^{0}\right)$ were quite similar among species except for $H$. emoryi, which had a low value (0.20), and $L$. tridentata, which had a high value (0.39), relative to the other studied species. Only E. farinosa, S. chinensis and $H$. emoryi had a $\Delta \mathrm{WD}^{0}>0.10$.

Variability in the volume-averaged elastic modulus (Tyree and Hammel 1972, Richter et al. 1980), or $E_{v a t}$, has been considered as a mechanism of adaptation to water stress (Roberts et al. 1981). The $E_{\text {vat }}$ is the slope of turgor potential vs. water deficit. The larger the value of $E_{v a t}$ the more rapidly turgor decreased with increasing water deficit. There is very little variation among species values of $E_{v a t}$. Therefore, because of the considerable error potential in measuring $E_{v a t}$ (Richter et al. 1980) and the small variation in $E_{v a t}$ between species, there seems to be no significant difference in elastic modulus characteristics between species.

Larrea tridentata, $S$. chinensis, A. greggii, and $P$. glandulosa had lower field, midday, leaf water potential than the leaf water potentials at the turgor loss point derived from predawn PV curves. This suggested either that diurnal osmotic adjustment may have been occurring because the reported PV relationships were col- lected on branches cut at dawn, or that negative turgor may have existed (Tyree 1976). For this reason, samples for PV analyses were collected at dawn and midday during September 1982.

All species exhibited diurnal osmotic adjustment except for L. tridentata (Fig. 10). The magnitude of diurnal osmotic adjustment varied among species, as shown in Table 2. Here we present the predawn and midday leaf water potential $(\psi)$, osmotic potentials $\left(\psi_{s}^{0}, \psi_{s}{ }^{100}\right)$, and water deficit at the turgor loss point $\left(\mathrm{WD}^{\circ}\right)$ for each species studied. Maximum diurnal osmotic adjustment occurred in S. chinensis, A. greggii, and P. glandulosa. Olneya tesota had little diurnal osmotic adjustment. There was no diurnal adjustment of the $\mathrm{WD}^{0}$ for any species. At predawn $P$. glandulosa and L. tridentata seemed to have slightly negative turgor, but these negative values are so small that it is most likely that small errors in leaf water potential and PV curve measurements are responsible. All other species had positive turgor at predawn, ranging from $1.21 \mathrm{MPa}$ for $A$. greggii to $0.63 \mathrm{MPa}$ for $S$. chinensis. At midday, P. glandulosa still had close to zero turgor even though there was an osmotic adjustment of $0.91 \mathrm{MPa}$. Acacia greggii and $S$. chinensis maintained turgor potential at midday only because of their large osmotic potential adjustment. Olneya tesota would have maintained turgor even if the small osmotic adjustment of $0.37 \mathrm{MPa}$ had not occurred. Larrea tridentata had a large estimated negative turgor at midday because no diurnal osmotic adjustment was measurable.

\section{DISCUSSION}

In past reports (Levitt 1980) phreatophytes have been described as deep-rooted trees with poor water use efficiency which survive in deserts by utilizing ground water to avoid the complications of water stress. However, the data collected in this study indicate that the phreatophytes are a diverse group which exhibit several mechanisms of avoiding and tolerating water stress, as previously suggested for $P$. juliflora and $P$. glandulosa (Mooney et al. 1977, Nilsen et al. 1983). The phreatophytes studied in this investigation can be placed in three categories based on their phenology and water 


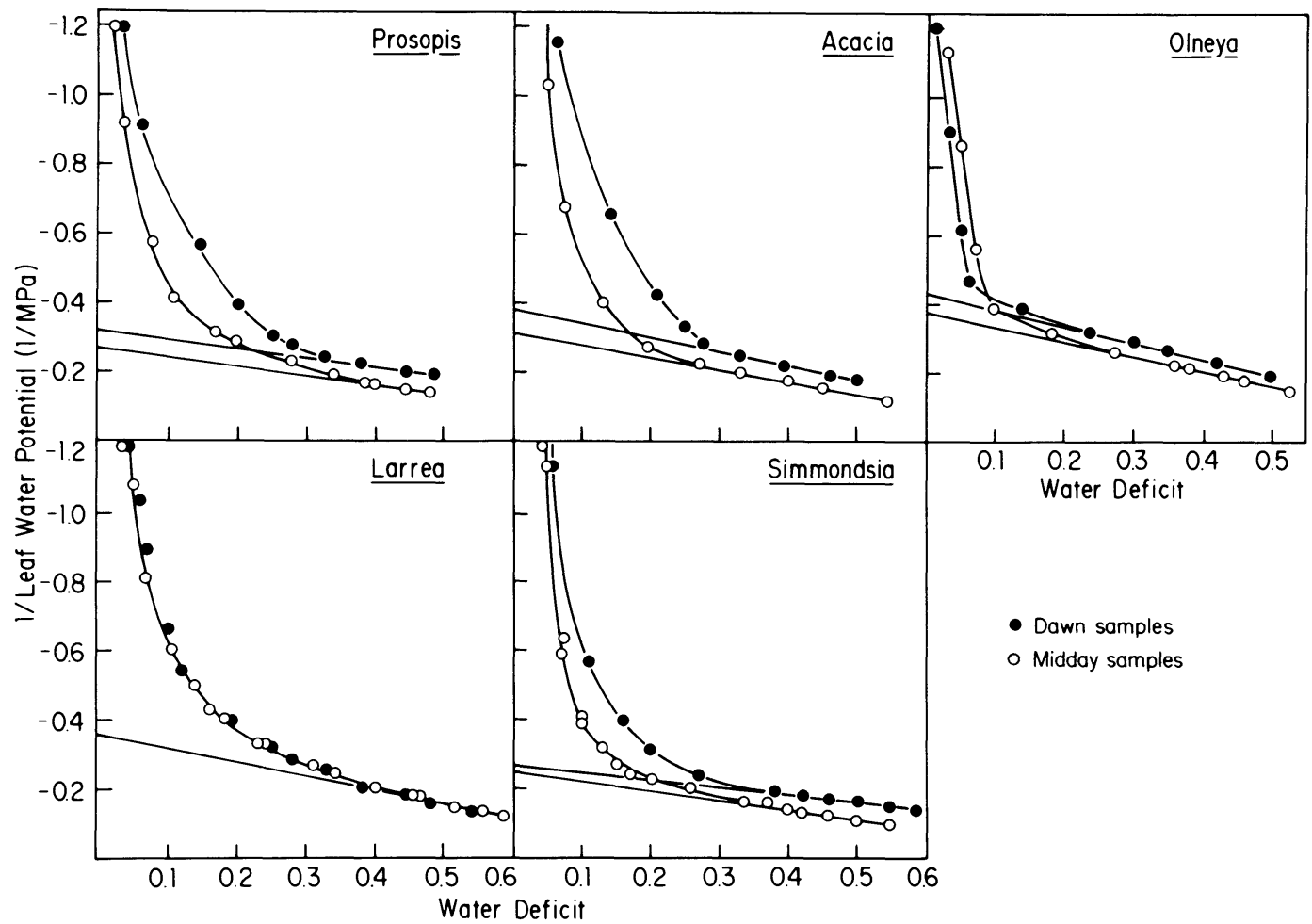

FIG. 10. Plots of pressure-volume (PV) curves derived from midday and dawn PV curve samples of five species from Nude Wash during September 1982. $(\mathbf{O}=$ dawn samples, $\mathrm{O}=$ midday samples).

relations parameters. Each category has a different suite of adaptations to the water deficiency imposed by the desert environment. These categories are winter-deciduous, summer-deciduous, and stem photosynthetic phreatophytes.

\section{Mechanisms of drought avoidance}

One classic mechanism of drought avoidance in desert plants is deciduousness during the driest and hottest period of the year, resulting in a reduction of transpi-

TABLE 2. Predawn and midday water relations parameters for five desert species derived from representative pressurevolume analyses for individuals during Spetember 1982, in Nude Wash of the Sonoran Desert, California. $\psi=$ leaf water potential; $\psi_{s}{ }^{100}=$ leaf osmotic potential at full turgor; $\psi_{s}{ }^{0}=$ leaf osmotic potential at the turgor loss point; WD $\mathrm{WD}^{0}=$ leaf water deficit at the turgor loss point; $\tau=$ leaf turgor potential.

\begin{tabular}{|c|c|c|c|c|c|}
\hline & $\begin{array}{l}\text { Prosopis } \\
\text { glandulosa }\end{array}$ & $\begin{array}{l}\text { Acacia } \\
\text { greggii }\end{array}$ & $\begin{array}{c}\text { Olneya } \\
\text { tesota }\end{array}$ & $\begin{array}{c}\text { Larrea } \\
\text { tridentata }\end{array}$ & $\begin{array}{l}\text { Simmondsia } \\
\text { chinensis }\end{array}$ \\
\hline \multicolumn{6}{|l|}{ Predawn } \\
\hline $\begin{array}{l}\psi(\mathrm{MPa}) \\
\psi_{s}^{100}(\mathrm{MPa}) \\
\psi_{s}^{0}(\mathrm{MPa}) \\
\mathrm{WD}^{0} \\
\tau(\mathrm{MPa})\end{array}$ & $\begin{array}{r}-3.96 \\
-3.03 \\
-3.85 \\
0.34 \\
-0.11\end{array}$ & $\begin{array}{r}-2.96 \\
-3.23 \\
-4.17 \\
0.30 \\
1.21\end{array}$ & $\begin{array}{r}-2.23 \\
-2.70 \\
-3.33 \\
0.23 \\
1.10\end{array}$ & $\begin{array}{r}-5.37 \\
-2.77 \\
-5.26 \\
0.39 \\
-0.11\end{array}$ & $\begin{array}{r}-4.33 \\
-3.70 \\
-5.00 \\
0.32 \\
0.63\end{array}$ \\
\hline \multicolumn{6}{|l|}{ Midday } \\
\hline $\begin{array}{l}\psi(\mathrm{MPa}) \\
\psi_{s}^{100}(\mathrm{MPa}) \\
\psi_{s}^{0}(\mathrm{MPa}) \\
\mathrm{WD}^{0} \\
\tau(\mathrm{MPa})\end{array}$ & $\begin{array}{r}-4.75 \\
-2.70 \\
-4.76 \\
0.34 \\
0.01\end{array}$ & $\begin{array}{r}-4.58 \\
-2.67 \\
-5.13 \\
0.30 \\
0.53\end{array}$ & $\begin{array}{r}-3.10 \\
-2.33 \\
-3.70 \\
0.23 \\
0.60\end{array}$ & $\begin{array}{r}-6.40 \\
-2.77 \\
-5.26 \\
0.39 \\
-1.14\end{array}$ & $\begin{array}{r}-5.90 \\
-4.00 \\
-6.25 \\
0.32 \\
0.85\end{array}$ \\
\hline \multicolumn{6}{|c|}{ (Midday)-(predawn) } \\
\hline $\begin{array}{l}\Delta \psi_{s}^{100}(\mathrm{MPa}) \\
\Delta \psi_{s}^{0}(\mathrm{MPa}) \\
\Delta \mathrm{WD}^{0}\end{array}$ & $\begin{array}{c}-0.33 \\
-0.91 \\
0.0\end{array}$ & $\begin{array}{c}-0.56 \\
-0.96 \\
0.0\end{array}$ & $\begin{array}{c}-0.36 \\
-0.37 \\
0.0\end{array}$ & $\begin{array}{l}0.0 \\
0.0 \\
0.0\end{array}$ & $\begin{array}{l}-0.30 \\
-1.25 \\
0.0\end{array}$ \\
\hline
\end{tabular}


rational surface area (Orshan 1954). There are many drought-deciduous species in the Sonoran Desert of California, including the widespread Encelia farinosa. The small leaf area during the summer also reduces water use and prevents the development of extremely low water potentials in these plants. Both $H$. emoryi and $C$. linearis utilize the drought-deciduous avoidance mechanism. Dalea spinosa is virtually leafless all year and similarly avoids water loss during the summer. Because the phreatophytes also utilize deep water, the water potentials of the summer-deciduous phreatophytes are not so low as summer-deciduous shrubs (E. farinosa, B. californica) during June through November. The phenology of the other phreatophytes is out of phase with temporal evaporative demand, since they are deciduous in the winter and maximum leaf area occurs during the summer. These species utilize ground water at depth to maintain high dawn water potentials in relation to the shallow-rooted species.

The magnitude of stomatal conductance can also be viewed as a mechanism of drought avoidance. As suggested by Monson and Smith (1982), very low conductance values act to inhibit water loss and conserve water to avoid water stress. Olneya tesota and $\mathrm{H}$. emoryi both have low conductance values compared to the other phreatophytes. The low conductance reduces water loss, resulting in the maintenance of higher water potentials than for those species with high conductance rates. The evergreen species in our study also had low conductance values for water conservation similar to those found by Strain (1975). It may be advantageous for evergreens to conserve water because they have relatively large leaf areas during the summer, and minimal competition for water exists between species of evergreens (Fonteyn and Mahall 1978). Dalea spinosa effectively maintains high dawn and midday water potentials by having a small leaf area, as does $C$. microphyllum (Adams et al. 1967).

Cucurbita was the most efficient avoider of low water potential. Its water potential values were always high (midday not below $-1.5 \mathrm{MPa}$ ) due to the short leaf longevity and the succulent root.

\section{Mechanisms of drought tolerance}

Several of the phreatophytic species maintained low seasonal and diurnal water potential in contrast to previous reports for phreatophytes (Szarek and Woodhouse 1977, Monson and Smith 1982). The low water potential values for $P$. glandulosa, A. greggii, and $O$. tesota suggest that mechanisms of drought avoidance must exist. The winter-deciduous phreatophytes did not experience water potentials so low as the evergreen, shallow-rooted species which are considered to have mechanisms of drought tolerance (Strain 1975, Bennert and Mooney 1979).

The maintenance of low plant osmotic potential is considered a mechanism of drought tolerance because turgor can be maintained at low plant water potentials (Hellebust 1976, Hsiao et al. 1976). The winter-decid- uous phreatophytes had low seasonal osmotic potentials which were almost as low as the shallow-rooted, evergreen species. The summer-deciduous and stem photosynthetic phreatophytes had high osmotic potentials. The ability to adjust osmotic potential over the season as water stress becomes more severe is also a mechanism for tolerating water stress. Prosopis glandulosa, O. tesota, A. greggii, and C. linearis had considerable seasonal osmotic adjustment in comparison to the other phreatophytes. Even though $C$. linearis is summer deciduous, there was a second growth period in the late spring/early summer. The leaves of the second growth period had lower osmotic potential than the leaves produced in the winter, resulting in large seasonal osmotic adjustments. The evergreen species had lower osmotic adjustments than the winter deciduous phreatophytes because their osmotic potentials were low throughout the year.

The ability to maintain turgor at low leaf water content (measured by $\mathrm{WD}^{0}$ ) was fairly consistent between species (0.22-0.39). Only L. tridentata maintained turgor to water deficits close to 0.40. Hyptis emoryi, on the other hand, lost turgor at low water deficits. The ability to maintain turgor at low leaf water content varied minimally between the studied phreatophytes in relation to the seasonal variation in osmotic adjustment.

Two of the winter-deciduous phreatophytes were able to maintain high conductance values at low water potentials. This enabled $P$. glandulos $a$ and possibly $A$. greggii to have high productivity in the desert environment (Felker 1979, Nilsen et al. 1982, Sharifi et al. 1982). The other phreatophytes, including the winter deciduous $O$. tesota, had lower conductance values similar to the evergreen and summer-deciduous shrubs.

The presence of diurnal osmotic adjustment was indicated by the midday water potentials, which were lower than those at the turgor loss point derived from the PV analyses. Diurnal osmotic adjustment occurred in $S$. chinensis, $P$. glandulosa, A. greggii and O. tesota, but not in L. tridentata, in September 1982. This diurnal osmotic adjustment was required to maintain turgor at midday for $S$. chinensis, A. greggii, and $P$. glandulosa. The diurnal adjustment for $P$. glandulosa just maintained zero turgor at midday. For $O$. tesota the small diurnal osmotic adjustment which occurred was not necessary for the maintenance of positive turgor. Larrea tridentata did not exhibit diurnal osmotic adjustment; as a result a large negative turgor $(-1.14$ $\mathrm{MPa}$ ) seemed to develop. Other authors have found the same discrepancy for L. tridentata (Monson and Smith 1982). Since negative turgor is theorized not to exist (Tyree 1976) the lack of diurnal osmotic adjustment in L. tridentata remains unexplainable.

\section{CONCLUSIONS}

Phreatophytes of the Sonoran Desert have a complex suite of water stress avoidance and tolerance mechanisms. Each species has a different complex of water 
stress adaptations. Prosopis glandulosa and $A$. greggii tolerate summer water stress by adjusting osmotic potential and maintaining high conductance in the morning through the summer months. Therefore, they attain maximum leaf area for photosynthesis during the summer. On the other hand, $O$. tesota adjusts osmotic potential to maintain turgor during the late summer, but this species also avoids early-summer water stress by maintaining low conductance rates. Chilopsis linearis and $H$. emoryi minimize water stress by their summer deciduous habit, and $C$. linearis adjusts the osmotic potential in a second set of leaves produced in early summer to maintain turgor at the early-summer, low, leaf water potential. Dalea spinosa has extremely small leaves, and therefore has a reduced leaf area all year, thus minimizing water stress in the summer. On the basis of the general adaptations to water stress, these phreatophytes can be placed into three categories which correspond with phenological catagories: (1) winterspring deciduous (P. glandulosa, A. greggii, O. tesota; (2) summer deciduous (H. emoryi, C. linearis); (3) stem photosynthetic-leafless (D. spinosa).

The variation in phreatophyte adaptations to water stress includes all mechanisms exhibited by the evergreen and deciduous desert shrubs in this study. In the study site the evergreen shrubs had lower osmotic potential and lower midday water potentials, but the winter deciduous phreatophytes had equivalent seasonal osmotic adjustment. This study clearly indicates that the desert phreatophytes are a diverse group with a complex set of adaptations to the desert environment.

\section{ACKNOWLEDGMENTS}

The cooperation of the staff of Anza Borrego State Park in making our research site available is much appreciated. Thanks are due to Karen Christensen for graphics, Drs. A. Hall of the University of California at Riverside and O. Lange (Würzburg) for suggestions about the use of the steady state porometer, and Drs. W. Jarrell and R. Virginia, both of the University of California at Riverside, for many helpful discussions. This research was supported by National Science Foundation grant number DEB 79-21971.

\section{Literature Cited}

Adams, M. S., B. B. Strain, and I. P. Ting. 1967. Photosynthesis in chlorophyllous stem tissue and leaves of $\mathrm{Cer}$ cidium floridum: accumulation and distribution of $\mathrm{C}$ from ${ }^{14} \mathrm{CO}_{2}$. Plant Physiology 42:1797-1799.

Bennert, W. H., and M. A. Mooney. 1979. Water relations of some desert plants in Death Valley, California. Flora 168:405-427.

Campbell, Gaylon S. 1977. An introduction to environmental biophysics. Springer Verlag, New York, New York, USA.

Cline, R. G., and G. S. Campbell. 1976. Seasonal and diurnal water relations of selected forest species. Ecology 57: 367-373.

Felker, P. 1979. Mesquite: an all-purpose leguminous arid land tree. Pages 89-132 in Gary A. Ritchie, editor. New agricultural crops. American Association for the Advancement of Science, Westview Press, Boulder, Colorado, USA.

Fonteyn, P. J., and B. E. Mahall. 1978. Competition among desert perennials. Nature 275:544-545.

Hastings, J. R., R. M. Turner, and D. K. Warren. 1972. An atlas of some plant distributions in the Sonoran Desert.
Technical Report Meteorology and Climatology of Arid Regions Number 21. University of Arizona Institute of Atmospheric Physics, Tucson, Arizona, USA.

Hellebust, J. A. 1976. Osmoregulation. Annual Review of Plant Physiology 227:485-507.

Hendrix, J. E. 1982. Sugar translocation in two members of the Cucurbitaceae. Plant Science Letters 25:1-7.

Hsiao, T. C., E. Acevedo, E. Fereres, and D. W. Henderson. 1976. Stress metabolism. Water stress, growth, and osmotic adjustment. Philosophical Transactions of the Royal Society of London 273:479-500.

Levitt, J. 1980. Responses of plants to environmental stress. II. Water, radiation, salt, and other stresses. Academic Press, New York, New York, USA.

Monson, R. K., and S. D. Smith. 1982. Seasonal water potential components of Sonoran Desert plants. Ecology 63:113-123.

Mooney, H. A., S. L. Gulman, P. W. Rundel, and J. Ehleringer. 1980. Further observations on the water relations of Prosopis tamarugo of the northern Atacama Desert. Oecologia (Berlin) 44:177-180.

Mooney, H. A., and J. Kummerow. 1979. The comparative water economy of representative evergreen schlerophyll and drought deciduous shrubs of Chile. Botanical Gazette 132: 245-252.

Mooney, H. A., B. B. Simpson, and O. T. Solbrig. 1977. Phenology, morphology, physiology. Pages $26-43$ in B. B. Simpson, editor. Mesquite: its biology in two desert ecosystems. Dowden, Hutchinson and Ross, Stroudsburg, Pennsylvania, USA.

Munz, P. A. 1974. A flora of southern California. University of California Press, Berkeley, California, USA.

Nilsen, E. T., P. W. Rundel, and M. R. Sharifi. 1982. Productivity in native stands of Prosopis glandulosa, mesquite, in the Sonoran Desert of southern California and some management implications. Symposium of California Riparian Ecosystems. University of California Press, Berkeley, California, USA.

Nilsen, E. T., M. R. Sharifi, and P. W. Rundel. 1981. Summer water relations of the desert phreatophyte Prosopis glandulosa in the Sonoran Desert of southern California. Oecologia (Berlin) 50:271-276.

Nilsen, E. T., M. R. Sharifi, P. W. Rundel, W. M. Jarrell, and R. A. Virginia. 1983. Diurnal and seasonal water relations of the desert phreatophyte Prosopis glandulosa. Ecology 64: 1381-1393.

Orshan, G. 1954. Surface reduction and its significance as a hydrological factor. Journal of Ecology 42:442-444.

Phillips, W. S. 1963. Depth of roots in soil. Ecology 44:424.

Poole, D. K., and P. C. Miller. 1981. Water relations of selected species of chaparral and coastal sage communities. Ecology 56:1118-1128.

Richter, H., F. Duhme, G. Glatzel, T. M. Hinkley, and H. Karlic. 1980. Pressure volume curves and their ecophysiological interpretation. Pages 263-273 in Plants and their atmospheric environment. Proceedings of the British Ecological Society.

Ritchie, G. A., and T. M. Hinkley. 1975. The pressure chamber as an instrument for ecological research. Advances in Ecological Research 9:165-254.

Roberts, S. W., K. R. Knoerr, and B. R. Strain. 1979. Comparative field water relations in four co-occuring forest tree species. Canadian Journal of Botany 57:1876-1882.

Roberts, S. W., B. R. Strain, and K. R. Knoerr. 1981. Seasonal variation in leaf tissue elasticity in four forest tree species. Physiologia Plantarum 52:245-250.

Scholander, P. F., H. T. Hammel, E. A. Hemmingson, and E. D. Bradstreet. 1965. Hydrostatis pressure and osmotic potentials in leaves of mangroves and some other plants. Proceedings of the National Academy of Sciences 51:119125.

Sharifi, M. R., E. T. Nilsen, and P. W. Rundel. 1982. Bio- 
mass and net primary production of Prosopis glandulosa (Fabaceae) in the Sonoran Desert of California. American Journal of Botany 69:760-767.

Slatyer, R. O. 1967. Plant water relationship. Academic Press, New York, New York, USA.

Smith, W. K., and P. S. Nobel. 1977. Influences of seasonal changes in leaf morphology on the water-use efficiency of three desert broadleaf shrubs. Ecology 58:1033-1043.

Smith, W. K., and P. S. Nobel. 1978. Influence of irradiation, soil water potential, and leaf temperature on leaf morphology of a desert broadleaf Encelia farinosa Gray (Compositae). American Journal of Botany 65:429-432.

Strain, B. R. 1970. Field measurements of tissue water potential and carbon dioxide exchange in the desert shrubs Prosopis julifera and Larrea divaricata. Photosynthetica 4: 118-122.

1975. Field measurements of carbon dioxide exchange in some woody perennials. Pages $145-158$ in D. M. Gates and R. B. Shmerl, editors. Perspectives in biophysical ecology. Springer-Verlag, Berlin, Germany.

Szarek, S. R., and R. M. Woodhouse. 1976. Ecophysiological studies of Sonoran desert plants. I. Diurnal photosyn- thetic patterns of Ambrosia deltoidea and Olneya tesota. Oecologia (Berlin) 26:226-234.

Szarek, S. R., and R. M. Woodhouse. 1977. Ecophysiological studies of Sonoran Desert plants. II. Seasonal photosynthesis patterns and primary production of Ambrosia deltoidea and Olneya tesota. Oecologia (Berlin) 28:365-375.

Tyree, M. T. 1976. Negative turgor pressure in plant cells. Fact or fantasy? Canadian Journal of Botany 54:2738-2746.

Tyree, M. T., and H. T. Hammel. 1972. The measurement of the turgor pressure and the water relations of plants by the pressure bomb technique. Journal of Experimental Botany $23: 267-282$.

Tyree, M. T., M. E. McGregor, A. Petrov, and M. I. Upenileks. 1978. A comparison of systematic errors between the Richards and Hammel methods of measuring tissuewater relation parameters. Canadian Journal of Botany 56: 2153-2161.

Walter, H., and E. Stadelman. 1974. A new approach to the water relations of desert plants. Pages $213-310$ in J. W. Brown, editor. Desert biology. Volume II. Academic Press. London, England. 